\title{
A VEGETAÇÃO COMO ACERVO BOTÂNICO NO PARQUE DO FLAMENGO, RIO DE JANEIRO
}

\author{
THE VEGETATION AS A BOTANICAL COLLECTION \\ IN THE PARQUE DO FLAMENGO, RIO DE JANEIRO
}

\author{
Ivete Mello Calil Farah
}

\begin{abstract}
Resumo
Este artigo trata dos aspectos botânicos relacionados ao projeto paisagístico destacando a vegetação como elemento relevante na concepção de paisagens urbanas. O ensaio exploratório é desenvolvido a partir do estudo de uma das mais importantes áreas de lazer do Rio de Janeiro - o Parque do Flamengo. O projeto paisagístico é de autoria de Roberto Burle Marx, que se destacou pelo uso inovador da vegetação, pautado pelos estudos da botânica e pelo assessoramento de profissionais da área. A análise é feita a partir da reflexão sobre quatro pontos: a diversidade vegetal característica do projeto; o uso de vegetação inédita em áreas urbanas; a presença de espécies em risco de extinção; e a utilização de plantas singulares na paisagem. Nesse último ponto, destaca-se a palmeira corifa (Corypha umbraculifera) e suas características peculiares. $\mathrm{O}$ artigo aponta para o valor como acervo botânico da vegetação de projetos paisagísticos em áreas urbanas e ressalta a necessidade de implementação de estudos científicos para maior conhecimento do comportamento das espécies vegetais nessas áreas, ampliando os subsídios para o uso dessa relevante ferramenta de projeto.
\end{abstract}

Palavras-chave: Projeto paisagístico. Vegetação. Parques. Parque do Flamengo. Roberto Burle Marx. Palmeira corifa.

\section{Abstract}

This paper focuses on the botanic aspects related to landscape architecture projetcts, highlighting the vegetation as a relevant element for designing urban landscapes. The exploratory essay is developed from the study of one of the most important leisure areas in Rio de Janeiro - the Parque do Flamengo. It was designed by Roberto Burle Marx, who stood out for his innovative use of vegetation, guided by the studies of botany and the advice of professionals in the area. Four topics support the analysis: the plant diversity caracteristic of the project; the unprecedented use of vegetation in urban areas; the presence of species at risk of extinction; and the use of unique plants in the landscape. Concerning the last point, the talipot-palm (Corypha umbraculifera) and its peculiar characteristics are highlighted. The paper points out the value of vegetation in landscape projects in urban areas as a botanic collection and emphasizes the need to implement scientific studies for greater knowledge about vegetation behavior in these areas, extending the subsidies for the use of this project tool.

Keywords: Landscape architecture project. Vegetation. Parks. Parque do Flamengo. Roberto Burle Marx. Talipot-palm. 


\section{INTRODUÇÃo}

A vegetação é um dos elementos mais potentes na paisagem, diversa em seus valores e múltipla em suas formas de utilização. Os projetos de espaços livres podem prescindir de seu uso, mas é fato que a presença do vegetal enriquece fortemente a paisagem. Desde os primórdios da concepção de espaços externos nas residências egípcias, nos pátios romanos e islâmicos, nas vilas italianas, a vegetação se impôs em seu papel de composição do ambiente e em seu apelo estético e afetivo. As cidades tardaram um pouco mais a apresentar o elemento vegetal em seus espaços públicos de forma sistemática e projetual, mas há mais de três séculos ele aparece incorporado de maneira indelével à paisagem urbana.

A vegetação urbana apresenta amplo espectro de atributos, incluindo tanto aspectos ecológico-ambientais, reforçados com a aplicação do conceito de infraestrutura verde e suas redes de espaços interconectados (Benedict \& McMahon, 2006), como estéticos e compositivos (Macedo, 1982). Ademais de contribuir com na melhoria da saúde e da qualidade de vida (Ulrith, 1990) e estabelece profundos elos emocionais com a população (Dwyer et al., 1994). Nesse quadro diversificado de suas propriedades, há de se considerar ainda os aspectos botânicos relacionados à presença do elemento vegetal em cidades, que serão o foco deste artigo.

Nossa proposta é refletir, a partir do caso do Parque do Flamengo, sobre as implicações relacionadas às espécies vegetais utilizadas no projeto paisagístico e seus valores botânicos. Investigamos essa questão por meio da discussão dos seguintes pontos: a aplicação da diversidade botânica, explorando elementos da flora nativa e de outros locais do planeta, inclusive pertencentes a diferentes domínios fitogeográficos; o uso inédito de algumas espécies em projetos paisagísticos; a presença de espécies em risco de extinção; e a utilização de plantas singulares na paisagem.

A pesquisa tomou por base a análise das listagens de espécies do projeto original e do inventário florístico de $1992^{1}{ }^{1}$, complementadas pela observação de campo e produção de registros da área

1 A nomenclatura botânica foi atualizada por meio da plataforma SiBBr (2018).

ao longo de décadas de pesquisas. O texto inicia-se com uma fundamentação teórica sobre o tema, seguida por um relato sobre o parque, contextualizando sua criação e descrevendo suas características, passando à discussão dos tópicos propostos, elencando espécies que auxiliam na ilustração dos pontos assinalados.

\section{Aspecto botânico do PROJeto paisagístico}

Os elementos vegetais, como seres vivos, pertencem a uma determinada espécie, que Ihe define características próprias, morfológicas, de comportamento e que exige necessidades ambientais específicas para sua sobrevivência. Segundo Clément (1995), cada planta traz uma mensagem, carrega informações que se referenciam a um clima, um ritmo de chuvas, uma força do vento e um solo, reportando a condições equivalentes à sua, em algum lugar do planeta. Sob esse ângulo, o autor compreende o jardim como um índex planetário.

A composição dessas mensagens entre si implica na compreensão de suas associações e possíveis complementações e estabelece uma escrita particular, que cada jardim, cada recorte de paisagem urbana com vegetação pode revelar. O projeto paisagístico envolve a definição do conjunto dessas mensagens, garantindo um discurso coerente com o partido pretendido e com a intenção da área no contexto urbano.

O valor botânico das espécies vegetais é comumente salientado e destacado nos Jardins Botânicos, locais relacionados ao conhecimento e com o objetivo de estudos científicos claramente explicitados. Historicamente, no Brasil, essas áreas vegetadas surgem inicialmente no século XIX, com a intenção de aclimatação de plantas exóticas, passando depois a ter atribuição científica. Como locais de cultivo e apresentação de acervo vegetal, a forma de distribuição no espaço atende prioritariamente à exposição das espécies, seja por tipos, famílias botânicas, origem ou grupo ecossistêmico.

Entretanto, outras áreas urbanas que dispõem de vegetação, seja com função principal de lazer ou ecológica, como parques e praças, podem se destacar como acervos botânicos, mesmo sem que a in- 
tenção principal seja científica ou educacional e com total liberdade para a definição e composição vegetal, de acordo com os conceitos projetuais adotados. Elas podem funcionar como laboratórios que informam sobre o desenvolvimento de espécies vegetais nas mais diferentes circunstâncias urbanas.

Outra questão relacionada ao caráter botânico da vegetação é que, no meio urbano, ela é exposta a uma grande variedade de habitats, sendo alguns com condições muito adversas e desgastantes (Spirn, 1995). São situações peculiares, quase sempre bem diferentes das do habitat natural da planta. Mesmo uma espécie autóctone, inserida no ambiente urbano de sua região, pode experimentar um microclima diverso de sua condição selvagem. No caso das espécies exóticas, isso pode ser ainda mais intensificado. $O$ estudo do comportamento dos exemplares vegetais nessas diferentes situações é um ponto fundamental para a compreensão da amplitude ambiental das espécies e da sua capacidade de adequação.

\section{Parque do Flamengo - Marco do Paisagismo Brasileiro}

O Parque do Flamengo, relevante área verde no Rio de Janeiro, teve projeto paisagístico de Roberto Burle Marx. A atuação do renomado paisagista se coloca como grande oportunidade de estudo dos aspectos botânicos do paisagismo. Seus projetos são resultado do jogo simbiótico da imaginação criativa e artística com a ciência e revelam sensíveis contribuições estéticas e ecológicas à arte dos jardins (Adams, 1991). Burle Marx buscava sempre ampliar os conhecimentos de botânica para subsidiar seus projetos com vegetação, além de se cercar de profissionais dessa área, realizando trabalhos em conjunto.

Localizado linearmente em área aterrada ao longo da orla da Baía de Guanabara, o Parque do Flamengo (Figura 1) possui em torno de 120 ha e é limitado, ao norte, pelo Aeroporto Santos Dumont e, ao sul, pela Praia de Botafogo. O desmonte do Morro de Santo Antônio, no início da década de 1950, gerou o material para a área do aterro, que restou desocupada durante alguns anos. Sua destinação para parque público deveu-se principalmente à Maria Carlota de Macedo Soares, com apoio político do recém-eleito Governador Carlos Lacerda (Costa, 1993). Lota, como era conhecida, indicou os profissionais para composição de equipe de projeto, formada, entre outros, por Affonso Eduardo Reidy, Roberto Burle Marx e o responsável pela área da botânica, Luiz Emygdio de Mello Filho. O projeto, iniciado em 1961, finalizou-se em 1965, e incluiu uma obra anterior - o Museu de Arte Moderna -, de autoria de Reidy, localizado no extremo norte do parque, com jardins também projetados por Burle Marx (1954-1958). Já outras áreas receberam plantios posteriores, como a da Marina da Glória e do entorno do antigo restaurante Rio's, na década de 1970 . Um trecho entre a Marina e a praia, que estava cercado desde a sua concessão, retornou ao uso público, recebendo alguns novos plantios, em 2016.

Considerado o primeiro parque de linhas modernas no Brasil (Costa, 1993), seu projeto representou uma inovação no desenho de espaços livres públicos. Em termos de tipologia urbana, possui características de parkway em função da presença de pistas expressas, que cortam áreas verdes destinadas ao lazer da população, ligando a zona sul ao centro da cidade. O cruzamento das circulações de pedestre e veículos é resolvido com a criação de desníveis ora com passagens subterrâneas para pedestres, ora com passarelas. O projeto tira partido da localização, compondo com a vegetação ambientes para a apreciação da privilegiada vista da Baía de Guanabara (Figura 2).

O tratamento paisagístico de Burle Marx se harmoniza ao traçado urbanístico de Reidy realçando as linhas sinuosas, em sintonia com a paisagem das montanhas circundantes e com o novo contorno da orla definido para a área aterrada (Motta, 1986). A seleção das espécies, tratando-se de área de parque, permitiu uma grande liberdade de escolha, sem limitação de porte ou tipos de raízes, como ocorre no caso de ruas ou praças. Segundo Mello Filho (1962), as premissas projetuais estabelecidas pela equipe de projeto tinham como objetivo a renovação tanto do ponto de vista da arquitetura paisagística como do elemento botânico utilizado, compreendendo o emprego de novas plantas em associações e arranjos originais.

O detalhamento da composição botânica foi revelado em 1992, por 


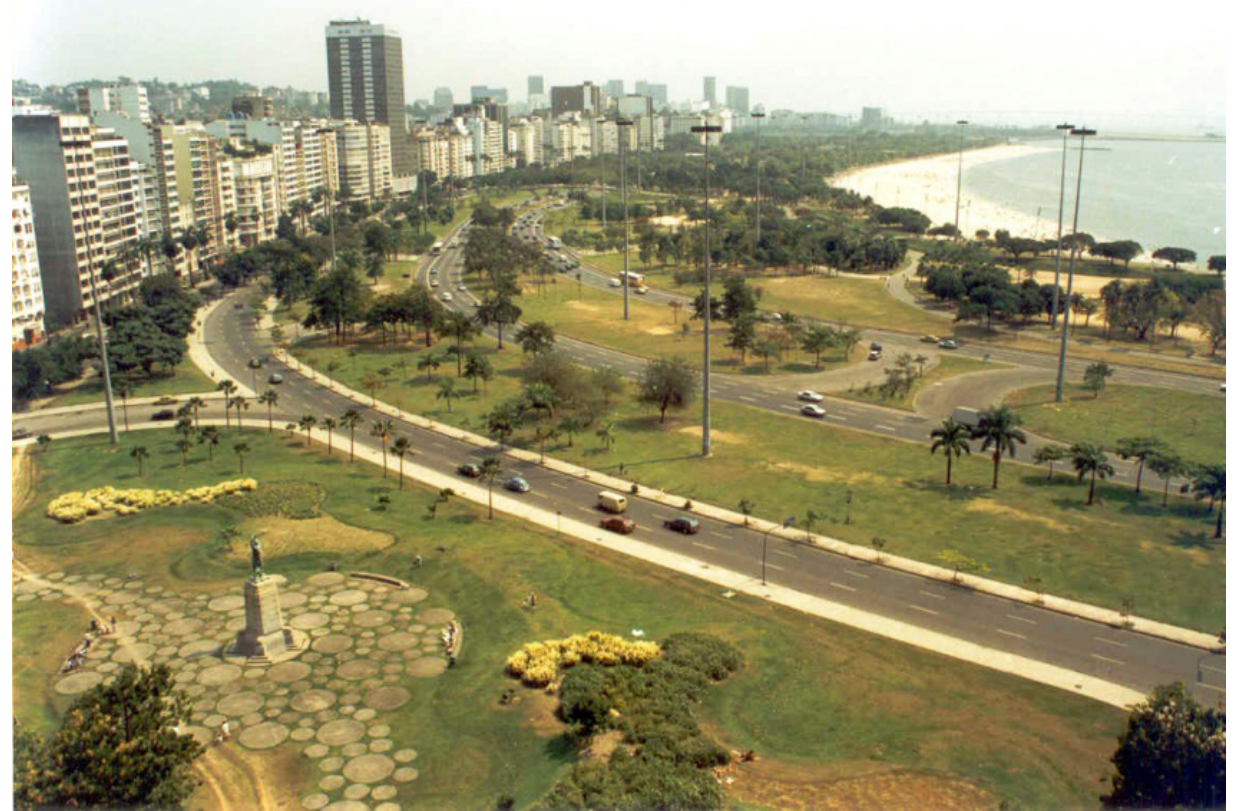

4

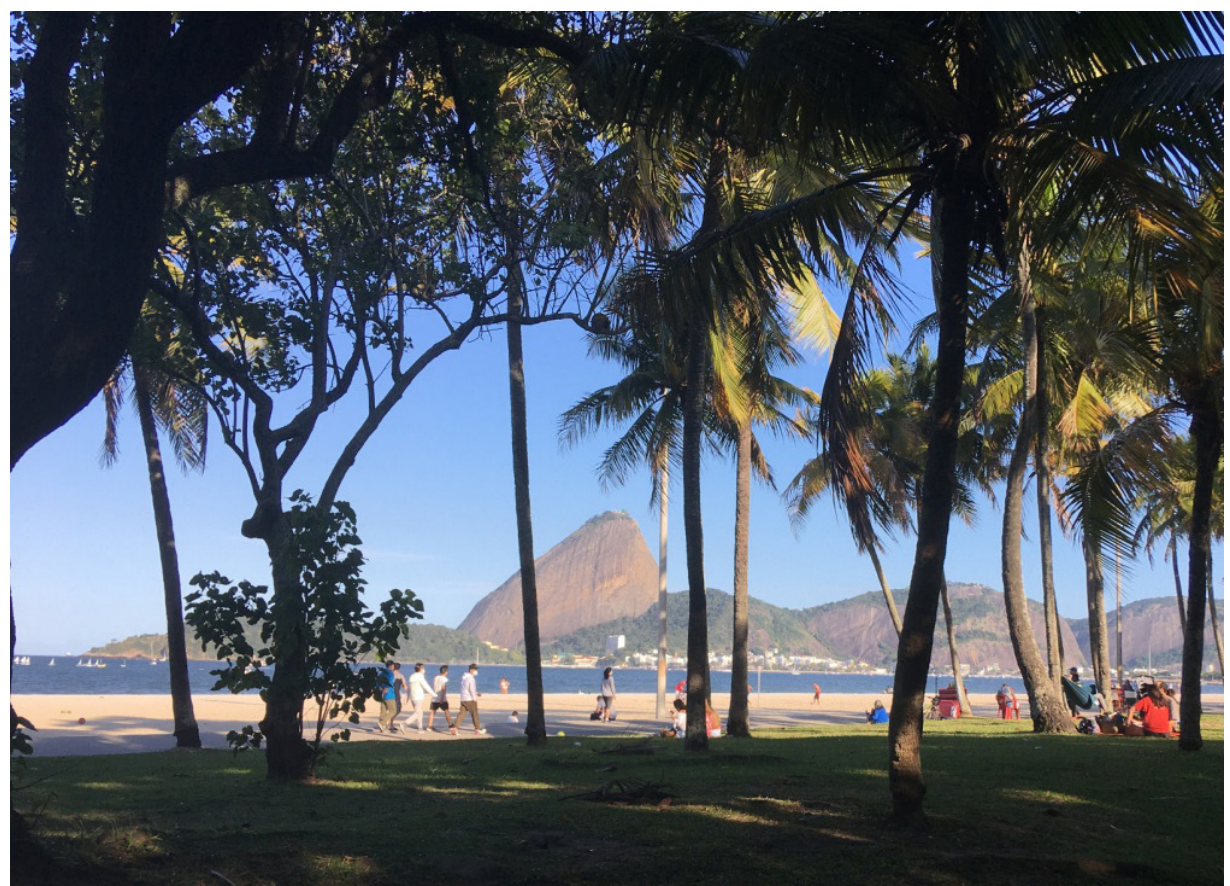

Figura 2: Vegetação criando enquadramentos para a paisagem da

Foto: Ivete Farah, 2021. Foto: Ivete Farah, 1992.
Figura 1: Vista do Parque do Flamengo. 
meio do inventário florístico do parque (Mello Filho et al., 1993) que indicou ter havido alteração do projeto original, com relação às espécies utilizadas. Muitas dessas modificações ocorreram ainda no momento da sua implantação, pela dificuldade de obtenção de mudas e pela substituição de espécies que não se adaptaram ao clima do local (Farah, 1997).

\section{Diversidade BotÂNICA}

O profissional do projeto paisagístico faz uso das espécies vegetais disponíveis na natureza de acordo com suas intenções conceituais, funcionais e ambientais. As opções estão lá, desde que conhecidas suas características, capacidade de adaptação ao ambiente urbano, em uma determinada situação de plantio. Outro importante condicionante é a sua disponibilidade no mercado de produção de mudas e o fato de que nem todas as espécies vegetais se adaptam à produção comercial

As variadas formas e características apresentadas pelo elemento vegetal são uma ferramenta poderosa na composição da paisagem urbana. A cada espécie utilizada, um novo e diferente espaço é conformado, com atributos próprios. Para Stefulesco (1993, p. 31), a diversidade proporciona à coletividade um mundo de sutilezas e encantamento, ao mesmo tempo que instrumentaliza a elaboração de projetos com vegetação, enriquecendo-os "em volumes, em estrutura, em transparências, em matéria e em cores".

Retomando a ideia de índex planetário citada anteriormente, cada planta é capaz de evocar a imagem da região de seu habitat natural, proporcionando uma "viagem no tempo e no espaço". A sua mensagem e a ideia que fazemos dela se sobrepõem ao objeto em si, fazendo passar do vernacular ao planetário (Clément 1995, p. 392). A diversidade de espécies, portanto, representa um ganho para a paisagem pela possibilidade de consciência da pluralidade do planeta.

De uma forma geral, nota-se nos espaços livres das cidades brasileiras pouca variedade de espécies vegetais. Esse quadro começa a apresentar mudanças, impulsionadas principalmente pela influência da atuação de Burle Marx que, com a articulação das potencia- lidades das diversas espécies, apontou um caminho a ser seguido.

O projeto paisagístico do Parque do Flamengo é um dos mais significativos exemplos de exploração da diversidade de espécies vegetais em área urbana. Burle Marx produziu uma paisagem com ordem e harmonia, a partir da concepção de composições que conciliam diferenças. Segundo Lynch (1990), o prazer da diferenciação é desejado, mas é necessário haver um todo orgânico dentro da rica complexidade, fugindo-se dos extremos de uma ordem monótona e cansativa e da desordem caótica. Burle Marx alcança esse equilíbrio, principalmente por meio do agrupamento de indivíduos da mesma espécie e pela composição desses entre si, articulando formas, volumes e cores.

A variedade vegetal do parque pode ser constatada tanto no número de espécies como na distribuição de seus exemplares. No inventário de 1992 foram levantadas 240 diferentes espécies, entre árvores, arbustos, forrações e aquáticas (Mello Filho et al., 1993), não havendo entre as árvores ${ }^{2}$ nenhuma com percentual de ocorrência maior do que $6 \%$ do número total de indivíduos. 0 conjunto engloba tanto espécies originárias do Brasil como de outros países, sendo aproximadamente $42 \%$ de nativas, diferente do que constava na especificação original, onde esse percentual era maior - em torno de $50 \%$. Acredita-se que a dificuldade para obtenção de mudas pode ter levado a uma diminuição de representantes da flora brasileira ao longo da implantação.

O uso de nativas em um projeto implica na valorização de elementos vegetais da flora brasileira, luta constante de Burle Marx que criticava o desconhecimento das plantas indígenas e a falta de atenção ao potencial de utilização desses elementos em áreas urbanas. O habitante da cidade conhece a planta que faz parte de seu mundo diário, aquela que está à sua porta, que lhe provém a sombra de seu percurso ao trabalho e o espaço para o lazer. Incluir elementos nativos nas áreas urbanas é uma forma de trazê-los para o convívio cotidiano, de aproximá-los da população e, assim, reforçar seus laços afetivos. Esse é um passo importante para o seu conhecimento e à conscientização na luta pela sua preservação por

\footnotetext{
2 As espécies arbustivas de pequeno porte não foram quantificadas por número de exem-
} plares, apenas as árvores e arvoretas. 
parte da própria população. O paisagista teve papel fundamental no incentivo do uso de nativas, mas, ainda hoje, coloca-se como um imenso desafio conceber um projeto utilizando vegetação autóctone, ou seja, espécie nativa da própria região, pela restrição da disponibilidade no mercado dessas espécies.

Apesar dessa defesa implacável, Burle Marx não se furtava ao emprego de exóticas em áreas caracterizadas como ecossistemas urbanos, desde que bem adaptadas e que guardassem uma relação de proximidade com a paisagem natural da região ou que pertencessem a biomas similares ao do local do projeto. Segundo Mello Filho (1962), o uso do elemento exótico não foi negligenciado no Parque do Flamengo para não se perder a oportunidade da inclusão de espécies de beleza extraordinária, como a paineira-vermelha (Bombax ceiba), entre outras. Originária da Índia, essa árvore tem forte impacto na paisagem tanto pela pujança de sua floração escarlate como pela estrutura dinâmica de seus galhos espessos, realçada na época de queda das folhas (Figura 3). Alguns elementos exóticos foram buscados para adaptação às condições severas de beira-mar, principalmente nas áreas de maior ação do vento e da salinidade, como a baga-da-praia (Coccoloba uvifera) e o algodoeiro-da-praia (Talipariti tiliaceum), além dos nativos disponíveis para essas condições.

Vale ressaltar que no inventário de 1992 foi encontrada, em pequeno número $(0,03 \%)$, uma espécie exótica considerada invasora - a leucena (Leucaena leucocephala), mas ela não constava na lista original do projeto. Essa planta certamente surgiu de forma espontânea no parque. A presença de espécies invasoras representa, aliás, a possibilidade de descaracterização do projeto, assim como a introdução de mudas pela população, principalmente de frutíferas, o que aponta para a necessidade do manejo adequado da área.

Pela grande variedade de espécies empregadas e pela sua escala, a implantação do parque constituiu um grande desafio. A criação de um horto, de caráter provisório ${ }^{3}$, para cultivo e produção de mudas

3 Atualmente desativado, o horto localizava-se onde, de acordo com o projeto original, era prevista a Área de Piquenique, que nunca foi executada, restando um bosque composto pela vegetação que ali se desenvolveu ao longo dos anos. localizado na própria área do aterro foi fundamental para o sucesso da empreitada. O fornecimento era feito pelo Departamento Municipal de Parques e Jardins, pelo Jardim Botânico do Rio de Janeiro e por outros locais mais distantes, inclusive com sementes encomendadas do exterior. Árvores e palmeiras já desenvolvidas foram transplantadas, aproveitadas de áreas oriundas de chácaras arrasadas para construção de prédios (Dourado, 2009). Em função do caráter incomum de algumas espécies, houve fornecimento também do Sítio Santo Antônio da Bica, como se chamava na época o Sítio Roberto Burle Marx (Fleming, 1996; Farah, 1997), local onde o paisagista, desde a aquisição da propriedade em 1949, fazia seus experimentos botânicos e que atualmente destaca-se pela coleção de 3500 espécies de plantas.

A diversidade vegetal conseguida no projeto do parque surpreende, considerando-se o material pobre empregado no aterro. Apesar das solicitações da equipe de execução de colocar solo com melhor matéria orgânica por cima, a empresa responsável pela continuidade do serviço foi reticente na aceitação, ficando vários locais prejudicados com relação à qualidade do solo. O problema foi parcialmente atenuado com o aporte de material de melhor qualidade do Morro do Querosene (Dourado, 2009).

Outro ponto a ser salientado com relação à diversidade do Parque do Flamengo é a presença de várias espécies de um mesmo gênero, o que normalmente é observado em coleções botânicas. O grupo com maior representação é o das figueiras (Ficus spp), com catorze espécies, das quais, seis são brasileiras. Os ipês também se destacam com cinco espécies nativas do gênero Handroanthus e três do Tabebuia, dentre as quais, uma exótica. Entre as palmeiras, as fênix (Phoenix spp) são encontradas em seis diferentes espécies, todas exóticas, além de híbridos naturais.

\section{Espécies de Diferentes Domínios Fitogeográficos BRASILEIROS}

No que tange à diversidade vegetal do Parque do Flamengo, destaca-se o fato de ser ilustrativa de diferentes domínios fitogeográficos brasileiros. Dentre as espécies nativas, a maioria é oriunda da 


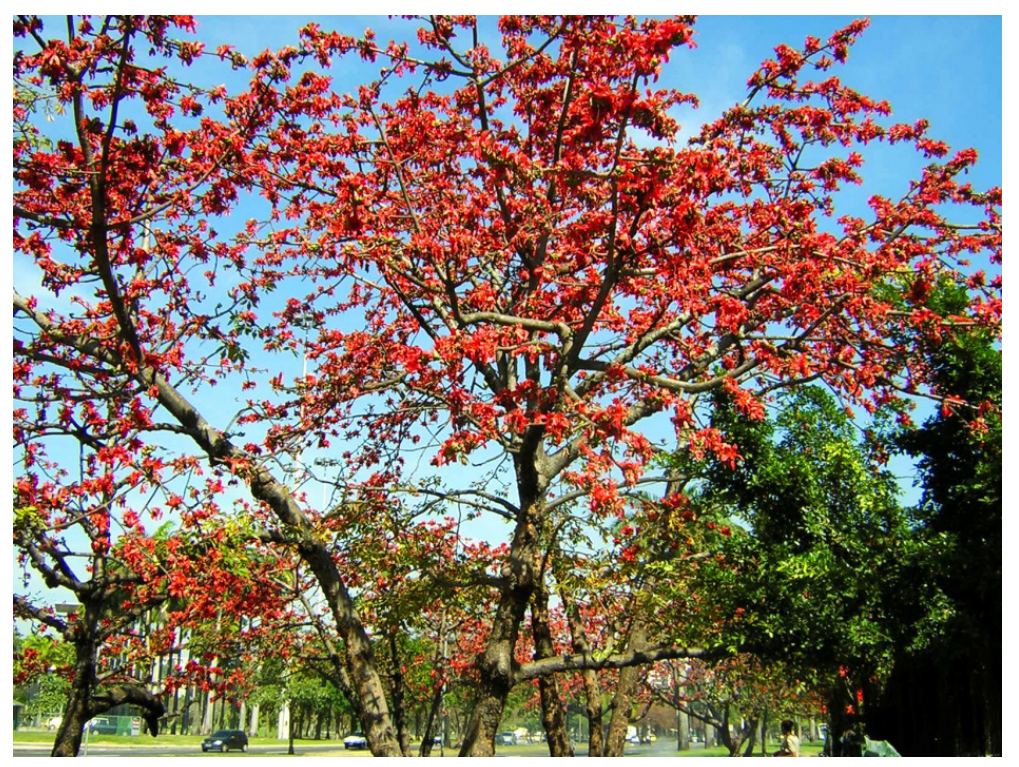

Figura 3: Conjunto de paineiras-vermelhas. Foto: Ivete Farah, 2008.

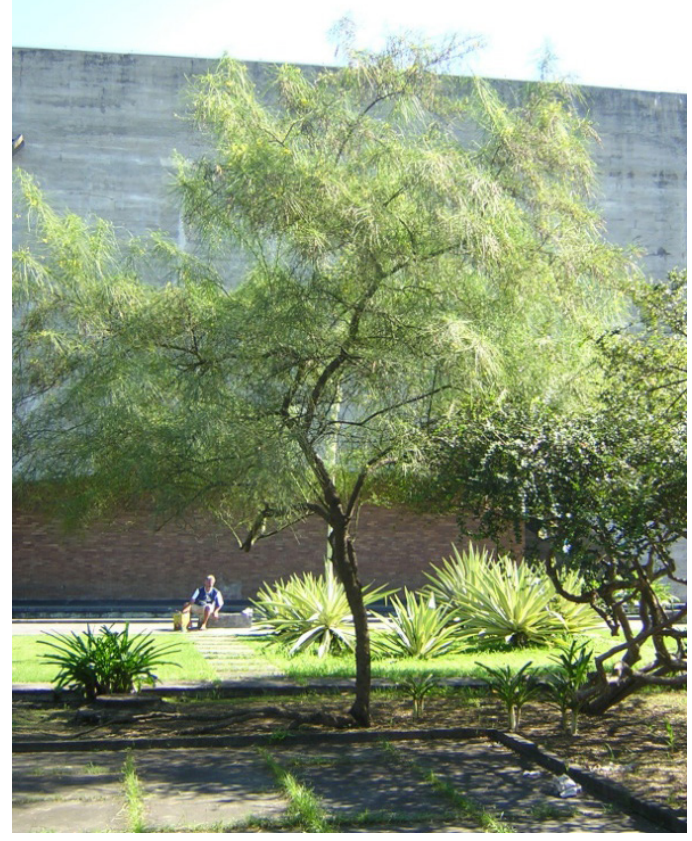

Mata Atlântica, tanto vegetação de restinga quanto de floresta. Há vários exemplares também da Floresta Amazônica. São encontradas ainda espécies pertencentes ao Cerrado, à Caatinga e ao Pantanal, em menor número. O abaneiro (Clusia fluminensis) é característico das restingas do litoral do Rio de Janeiro à Bahia. Há inúmeros representantes das florestas da Mata Atlântica como o pau-ferro (Libidibia ferrea var. leiostachya), o mulungu-do-litoral (Erythrina speciosa), o ipê-roxo (Handroanthus heptaphyllus), o pau -rei (Pterygota brasiliensis), entre outros. A região Amazônica tem representantes como o pau-mulato (Calycophyllum spruceanum) e o açacu (Hura crepitans). Um belo exemplo de vegetação da Caatinga é o turco (Parkinsonia aculeata) (Figura 4). Há ainda várias espécies que não ocorrem exclusivamente em um único bioma. $\mathrm{A}$ aroeira (Schinus terebinthifolia) viceja do nordeste ao sul do país em várias formações vegetais, enquanto a quixabeira (Sideroxylon obtusifolium) (Figura 5) encontra-se em várzeas e beiras de rios na caatinga nordestina, em restingas litorâneas e na mata do Pantanal Matogrossense. Já a cássia-rosa (Cassia grandis) ocorre na Região Amazônica, na Mata Atlântica e no Pantanal Matogrossense (Lorenzi, 2009, 2008, 1998).

\section{Diversidade de Palmeiras}

O emprego de vegetação pertencente ao grupo vegetal ${ }^{4}$ das palmeiras representa uma grande oportunidade projetual, pelo seu especial interesse paisagístico. Segundo Mello Filho (1962), elas são expressões vegetais das mais típicas da flora brasileira, o que é revelado, por exemplo, pelo termo pindorama (terra das palmeiras), apelido indígena dado ao Brasil.
Figura 4: Exemplar MAM.

Foto: Ivete Farah, 2006 de turco, próximo ao

No Parque do Flamengo, as palmeiras são exploradas de forma particular. Burle Marx utilizou mais de cinquenta espécies, entre nativas e exóticas adaptadas, configurando uma verdadeira coleção, digna de jardins botânicos, em pleno espaço livre público carioca. Também com relação às palmeiras do parque, a diversidade envolve domínios fitogeográficos variados e espécies com maior ou menor área de ocorrência.

4 As palmeiras integram a mesma família botânica: Arecaceae. 


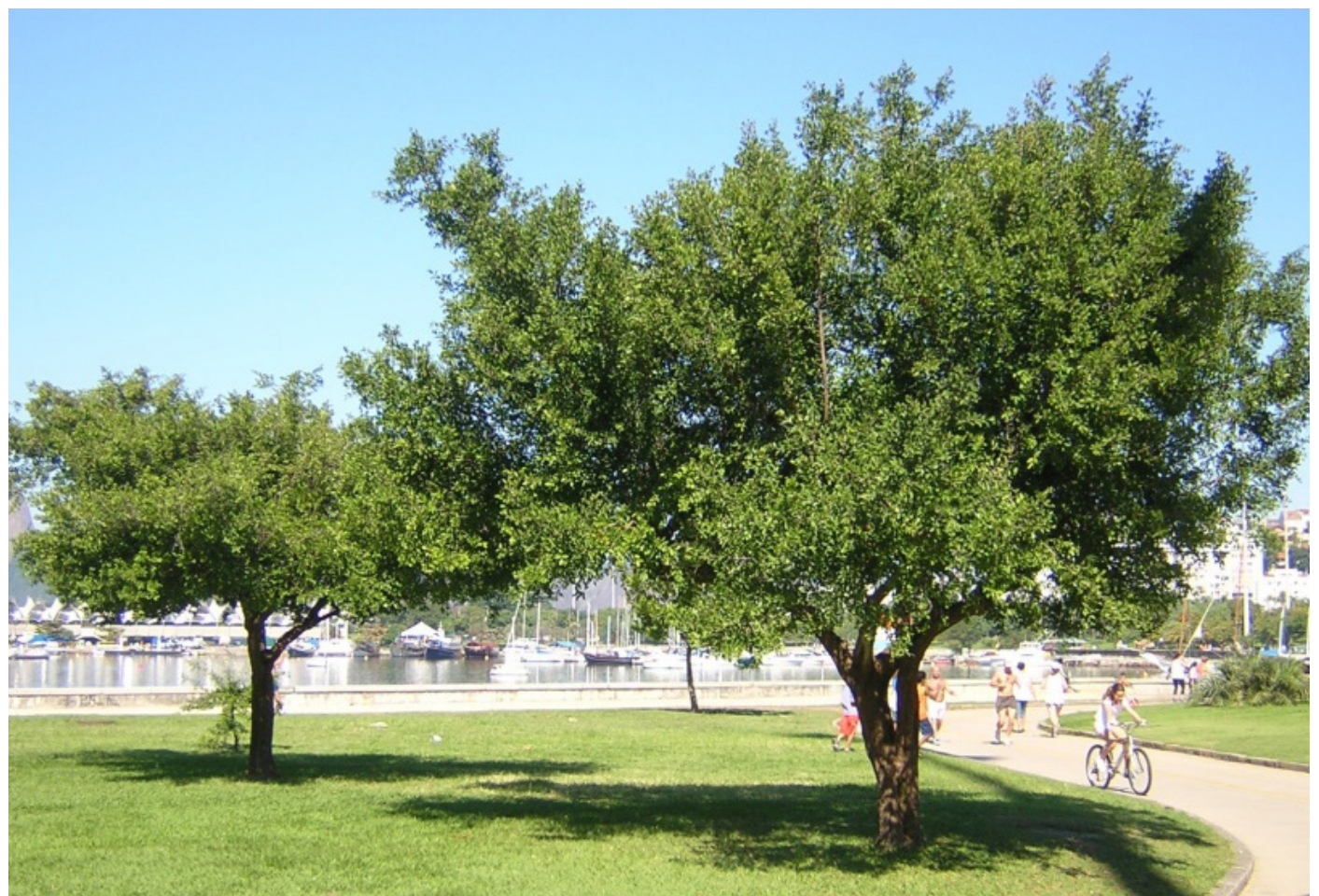

Figura 5: Quixabeiras face ao mar.

Foto: Ivete Farah, 2006

Duas palmeiras se destacam pela estrutura inusitada para o grupo vegetal. A guriri (Allagoptera arenaria) (Figura 6), característica de restinga de diversos estados brasileiros, de Pernambuco a São Paulo, tem caule subterrâneo, o que faz com que tenha aparência de arbusto. A outra é a cerca-onça (Desmoncus orthacantos), que se diferencia pelo hábito arbustivo no campo e como trepadeira na floresta. Ocorre em restinga, na Mata Atlântica e na Floresta Amazônica, com grande distribuição pelo país. Além desses domínios, há palmeiras representantes do Cerrado, como o coco-do-campo (Syagrus flexuosa) (Figura 7), palmeira entouceirada de pequeno porte (Lorenzi et al., 1996).

\section{Espécies Introduzidas em Paisagismo}

A curiosidade e a incessante busca pelo novo, traços da personalidade de Burle Marx, aliadas ao seu fascínio pela vegetação, impulsionaram o paisagista à introdução de um grande número de espécies vegetais no paisagismo, o que representou uma ampliação da cartela vegetal para os profissionais da área. Sua sensibilidade de observação permitiu a descoberta do potencial de valores vegetais pertencentes à flora brasileira, como também originários de outros países. Dentre esses últimos, o fato de serem comumente trazidos de locais com biomas semelhantes aos do Brasil fez com que não apenas se adaptassem facilmente às condições climáticas do país, como também se harmonizassem à nossa paisagem.

Os conhecimentos de botânica de Burle Marx davam embasamento a essa sensibilidade. $O$ paisagista sabia que recolher uma planta da floresta e levá-la para um jardim era retirá-la do anonimato, trazendo-a para perto das pessoas (Motta,1986). Um gesto de ousadia, que ilumina e propicia uma nova experiência.

A procura por esses elementos inéditos era feita tanto em excursões que realizava em áreas naturais de várias regiões do Brasil, acompanhado de sua equipe e de botânicos, como em viagens ao 


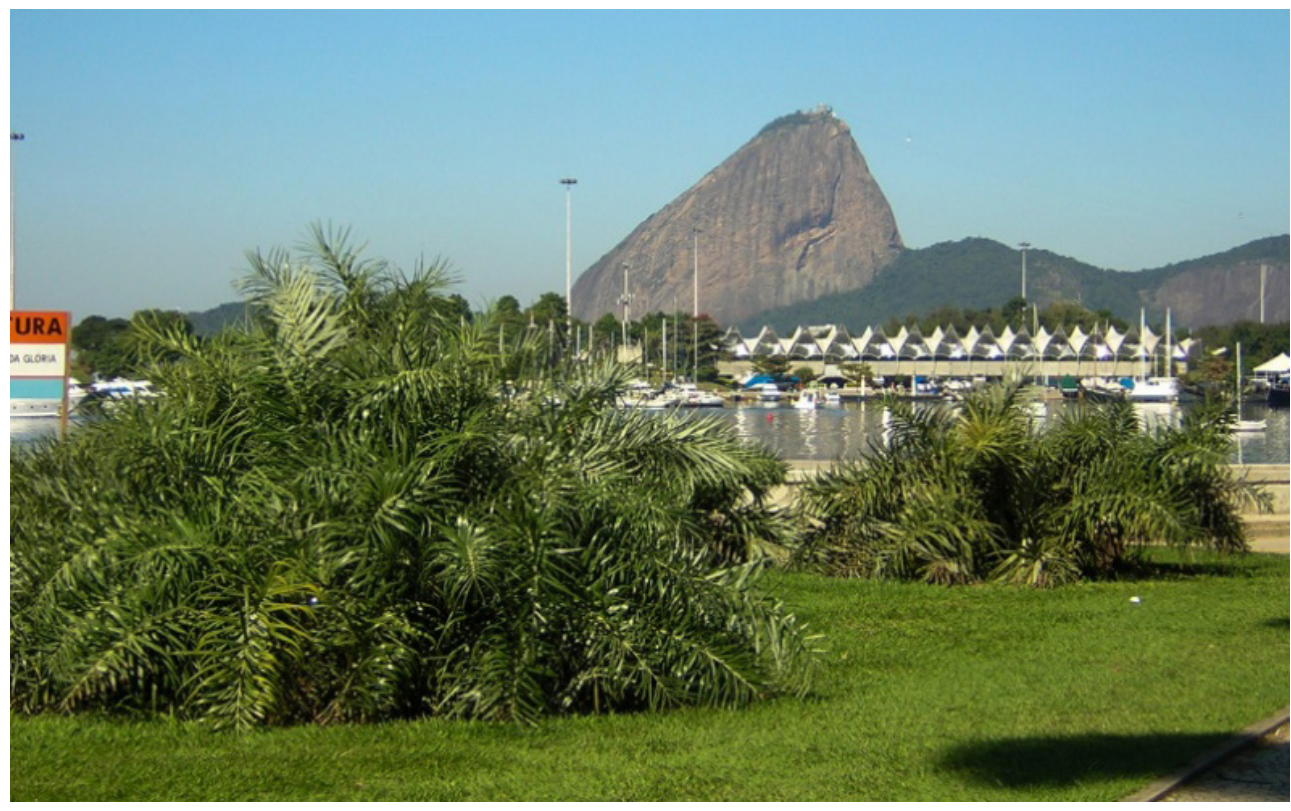

Figura 6: Grupos de guriris

Foto: Ivete Farah, 2006.

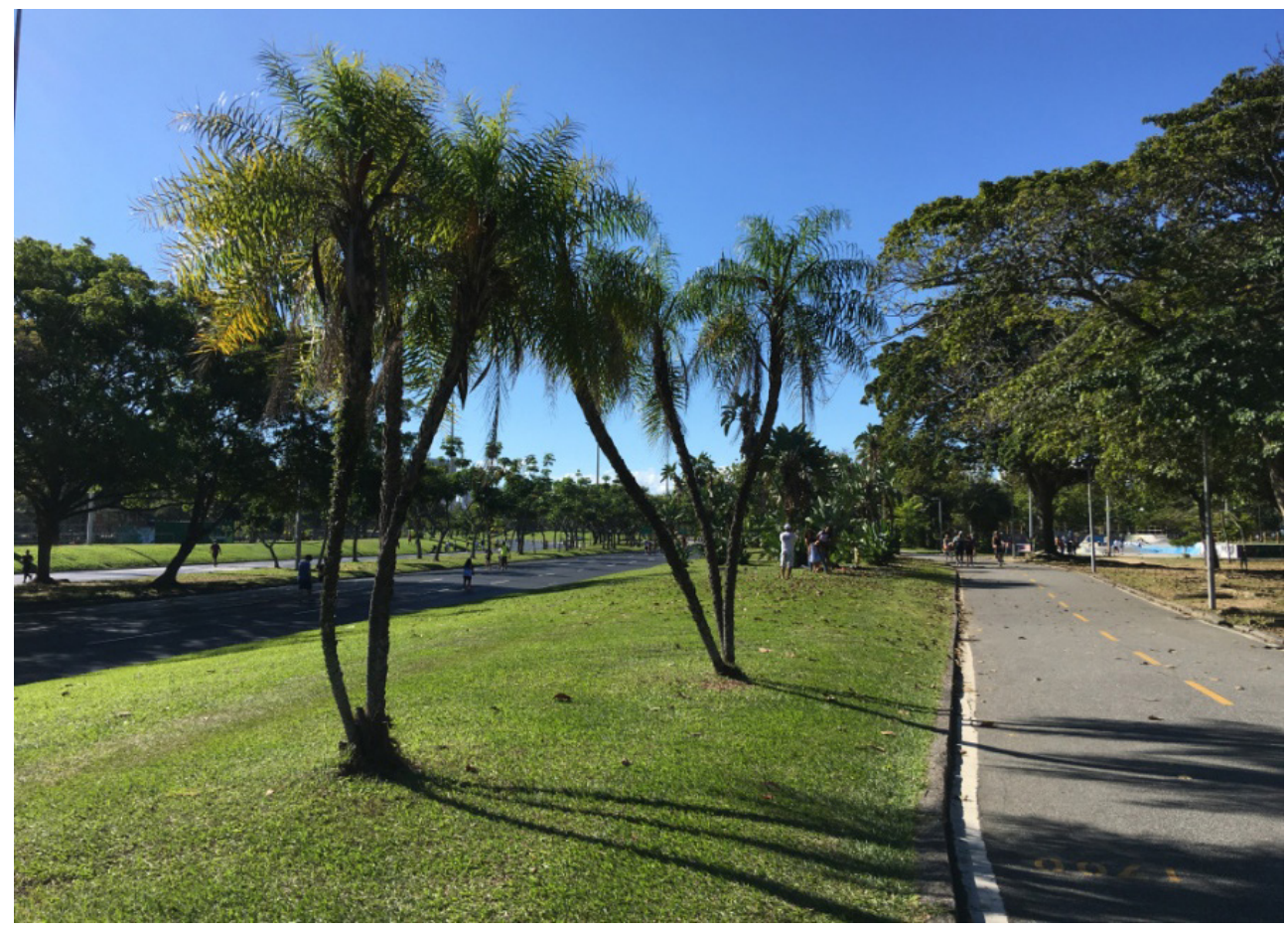

Figura 7: Exemplares de coco-do-campo.

Foto: Ivete Farah, 2021. 
exterior. A cada viagem que fazia, novas espécies eram coletadas e reproduzidas no Sítio Santo Antônio da Bica. Outra fonte se constituía por intermédio da troca de listagens de espécies com instituições de diferentes países, que resultava na aquisição de sementes de plantas não cultivadas por aqui (Farah, 1997).

No Parque do Flamengo podem ser encontradas muitas dessas espécies que tiveram seu uso paisagístico inaugurado por Burle Marx. Mello Filho (1994, p. 76) afirma que o projeto do parque "comportou-se como um macro-experimento em paisagismo ecológico", pela introdução de espécies vegetais pela primeira vez em espaços livres urbanos. A vegetação foi exposta à atuação de fatores climáticos e micro-climáticos, tendo que apresentar adaptação à influência marinha.

A introdução do pique-de-gazela (Acacia seyal) (Figura 8) representa um ganho significativo para o paisagismo brasileiro. A textura delicada de sua copa e o tom ferrugíneo de seus galhos e tronco atraem os visitantes do parque. $\mathrm{O}$ embiruçu (Pseudobombax elliptiárvore, originária do México, brinda a paisagem carioca com o espetáculo de suas flores magenta na primavera. Ainda pouco disseminada pelo restante do país, a inclusão dessa espécie pelo paisagista constitui uma singularidade para a cidade do Rio de Janeiro. Essas duas árvores tiveram uso inaugural no parque, como também o coco-do-campo e a quixabeira, mencionados anteriormente. A paineira-das-escarpas (Ceiba erianthos) (Figura 10), espécie das formações rochosas fluminenses, da Bahia e do Espírito Santo, foi utilizada pela primeira vez em áreas urbanas por Burle Marx no projeto da Praça Salgado Filho em 1947, e replicada no Parque do Flamengo.

A participação de Luiz Emygdio de Mello Filho foi fundamental na introdução de diversas espécies no Parque do Flamengo, tendo sido ele próprio responsável pela descoberta de novos valores paisagísticos. Das janelas de sua residência, o botânico observava o guamirim (Myrcia guianensis) (Figura 11), coberto com suas flores brancas, nas encostas do Morro da Viúva. Mello Filho fez a coleta e o introduziu no projeto de forma inédita ${ }^{5}$. O uso do jaca-

5 Entrevista com o Prof. Luiz Emygdio de Mello Filho, em 23/04/1996. Nomenclatu-

ra referenciada na ocasião: Myrcia obtecta.

ré (Chloroleucon tortum) (Figura 12), espécie de restingas e matas brasileiras, foi resultado de uma pesquisa realizada com Burle Marx (Mello Filho, 1962). Durante uma expedição em Cabo Frio, o botânico apresentou a planta ao paisagista, que se encantou com sua forma retorcida.

Um caso bem peculiar de uso inédito é a Erythrina $\mathrm{x}$ fluminensis (Figura 13), híbrido natural introduzido por Luiz Emygdio de Mello Filho no Parque do Flamengo. A espécie surgiu no horto do Museu Nacional, identificada como hibridização de Erythrina fusca com a Erythrina speciosa. O botânico levou-a para o horto do Parque, onde foram reproduzidas as mudas que hoje lá estão (Farah, 1997).

\section{Espécies em Perigo}

A presença de espécies nativas que estejam em risco de extinção em áreas urbanas pode ser uma forma de chamar atenção da população e de gestores públicos para a perda de valores da flora brasileira. A utilização dessas espécies em áreas urbanas não é um paliativo nem de forma alguma diminui a necessidade dos procedimentos para a sua preservação em áreas naturais. Mas, apesar de exemplares isolados, fora de seu habitat, podem se transformar em símbolos da luta pela sua preservação, além de proporcionar a coleta de sementes para produção de novos indivíduos.

O Parque do Flamengo apresenta em seu acervo botânico algumas espécies que integram a lista das ameaçadas de extinção. De acordo com o Projeto Lista Vermelha, desenvolvido pelo CNCFlora Centro Nacional de Conservação da Flora ${ }^{6}$, o pau-brasil (Paubrasilia echinata) foi classificado na categoria "em perigo"; o coco-azedinho (Butia capitata) e a gameleira-grande (Ficus cyclophylla) estão na categoria "vulnerável", já o jacaré integra a categoria "quase ameaçada" (Martinelli e Moraes, 2013), que o indica como suscetível de ameaça em um futuro próximo.

\footnotetext{
60 CNCFlora é uma coordenação do Instituto de Pesquisas Jardim Botânico do Rio de Janeiro responsável por pesquisas sobre biodiversidade e conservação da flora brasileira ameaçada de extinção. No Projeto Lista Vermelha, há três categorias para espécies ameaçadas: "criticamente em perigo", "em perigo" e "vulnerável".
} 


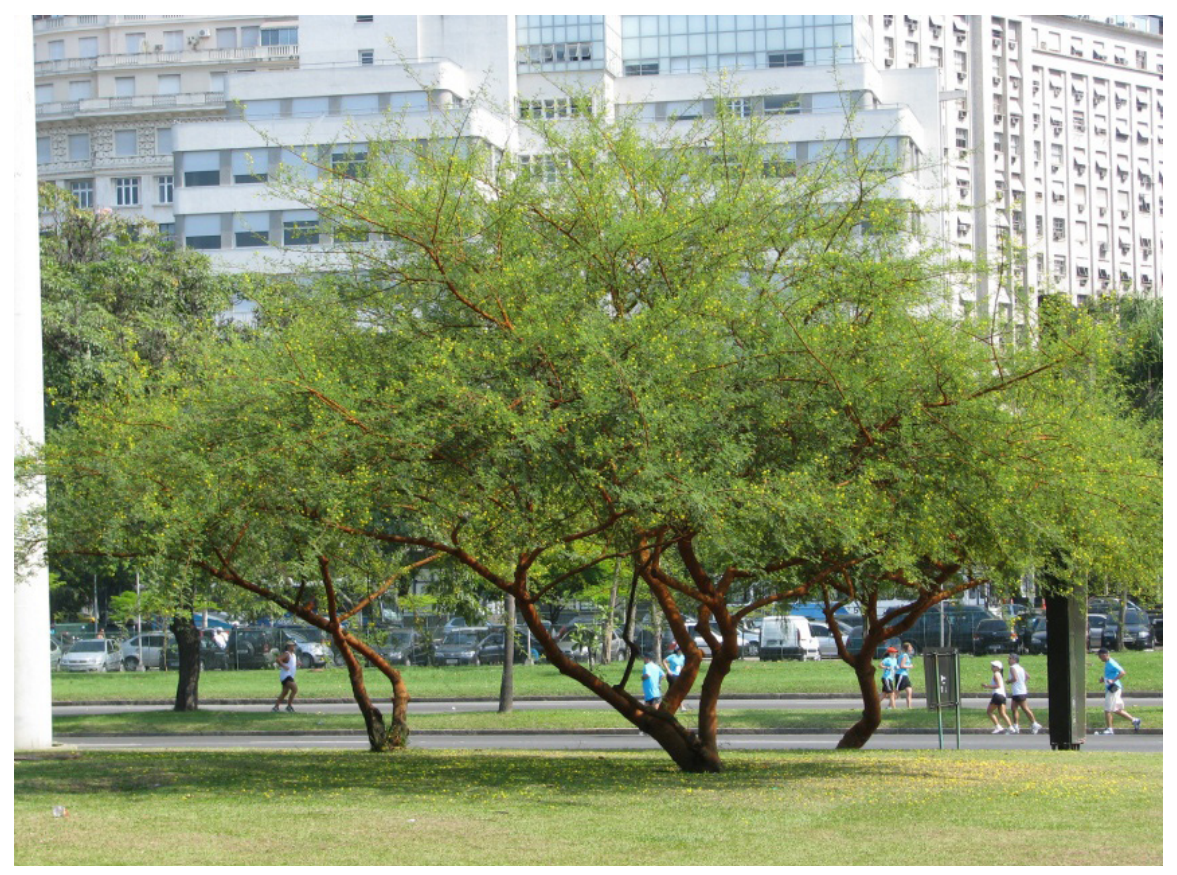

Figura 8: Pique-de-gazela e suas pequenas flores amarelas. Foto: Ivete Farah, 2008

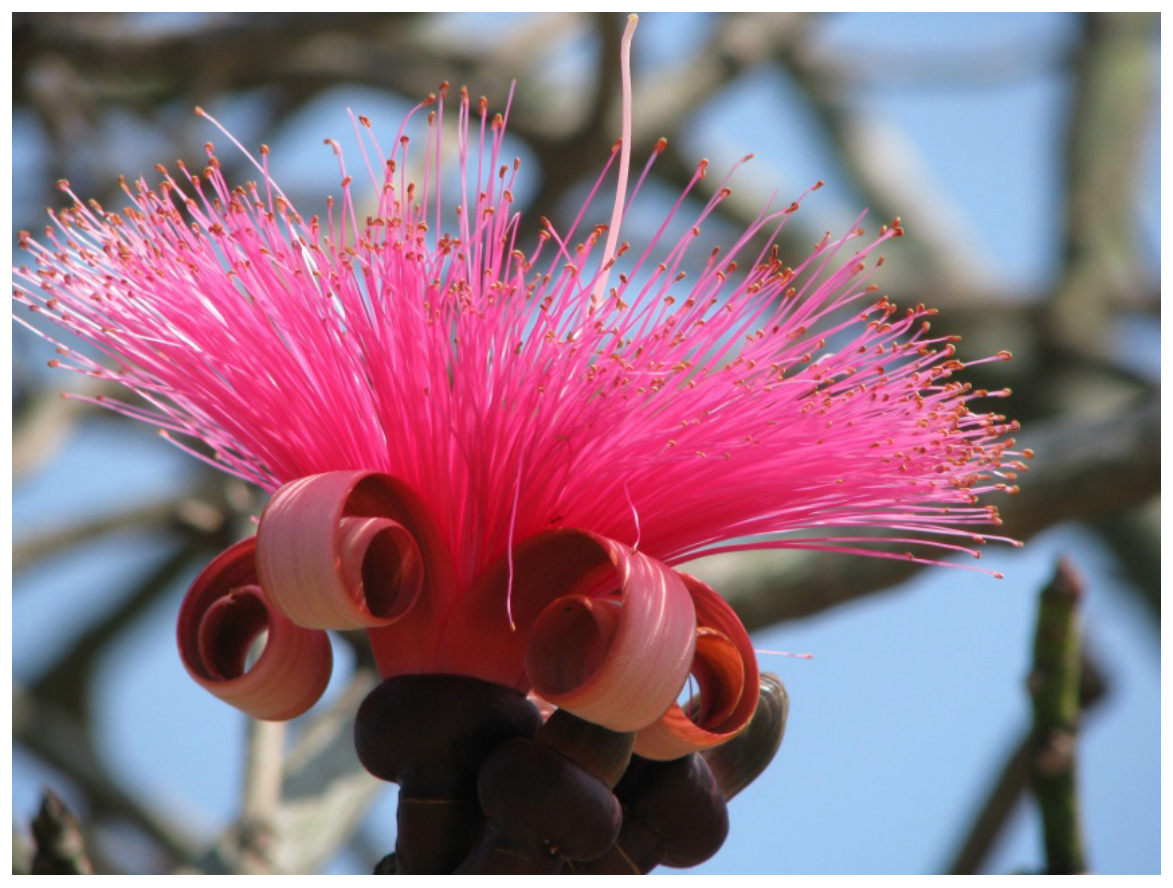

Figura 9: Detalhe da flor do embiruçu.

Foto: Ivete Farah, 2008. 


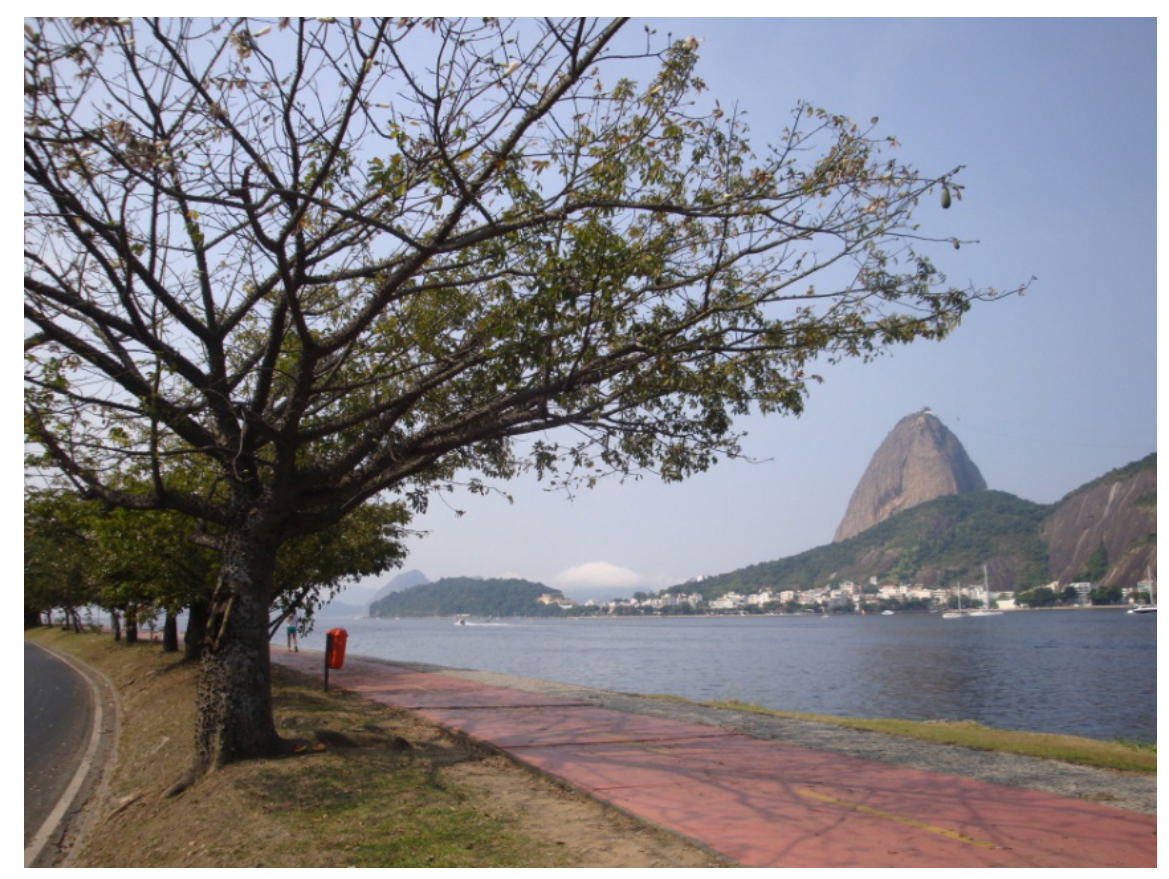

12

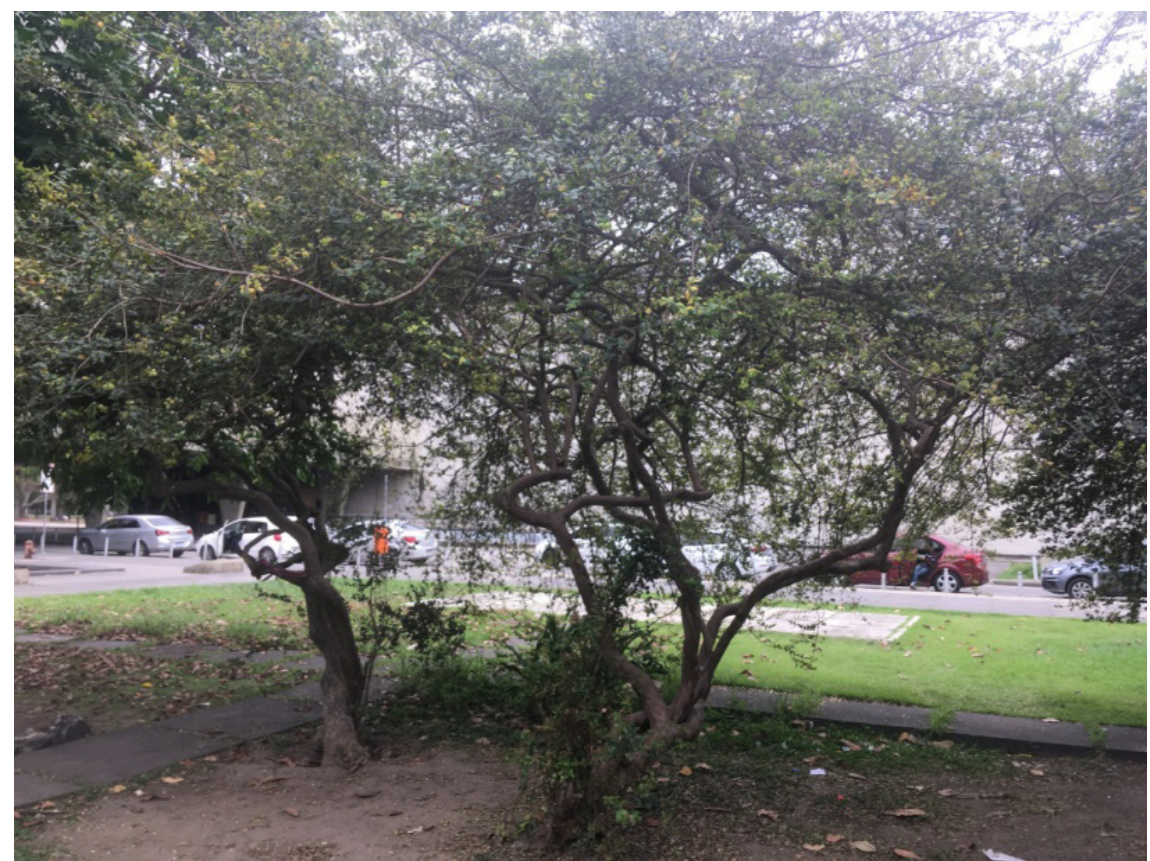

Figura 11: Grupo de guamirim

Foto: Ivete Farah, 2021. Foto: Ivete Farah, 2013.

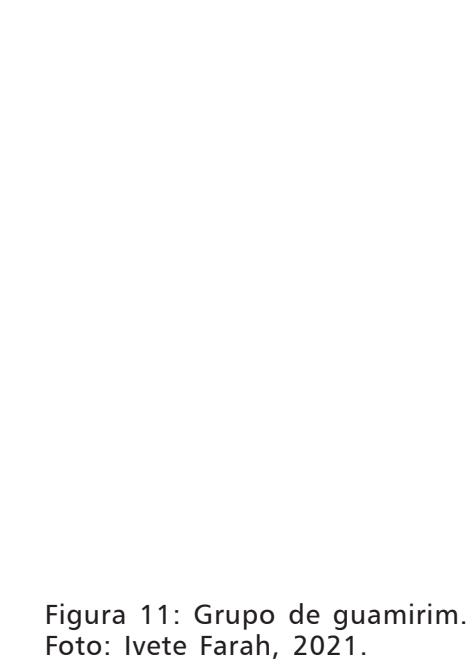

Figura 10: Exemplar de paineira-das-escarpas iniciando floração. 


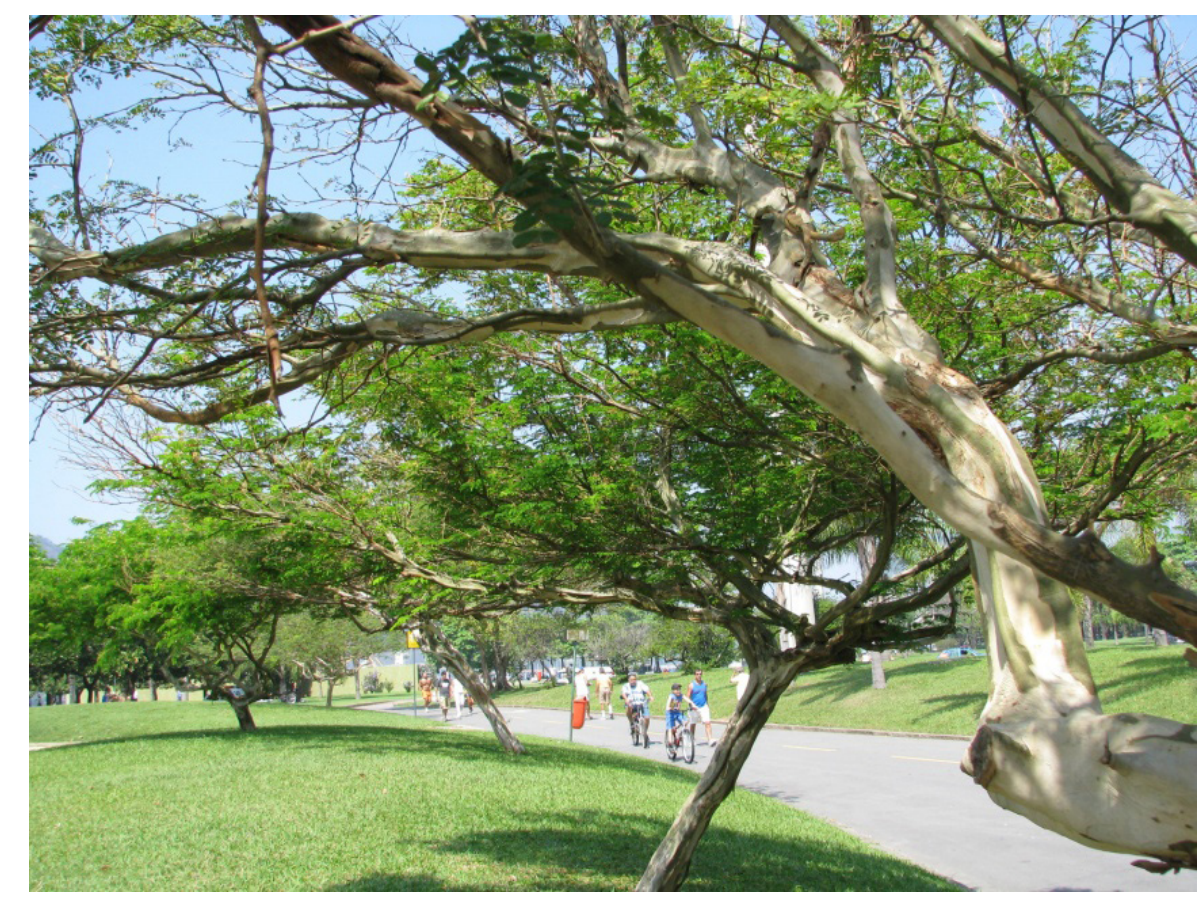

Figura 12: Grupo de jacarés e seus troncos desenhados e retorcidos. Foto: Ivete Farah, 2008

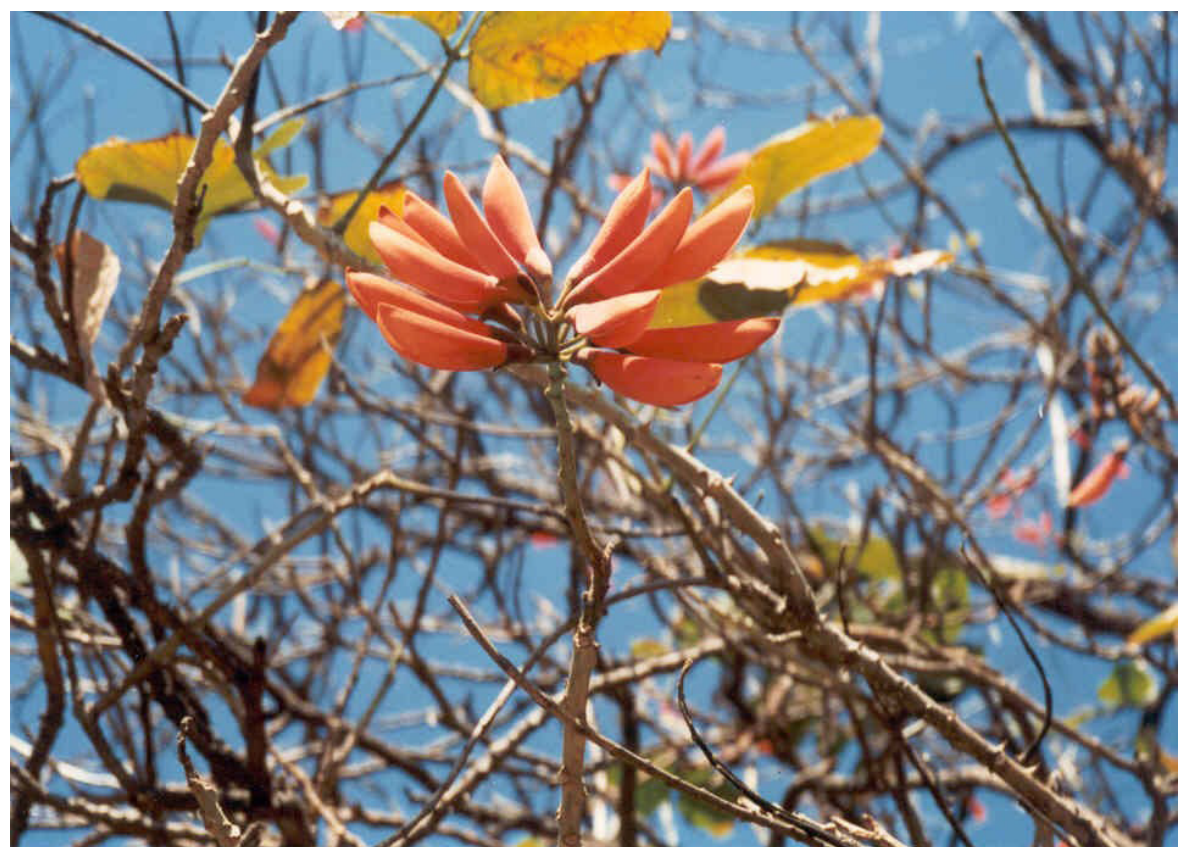

Figura 13: Detalhe da flor de Erythrina x fluminensis. Foto: Ivete Farah, 1994 


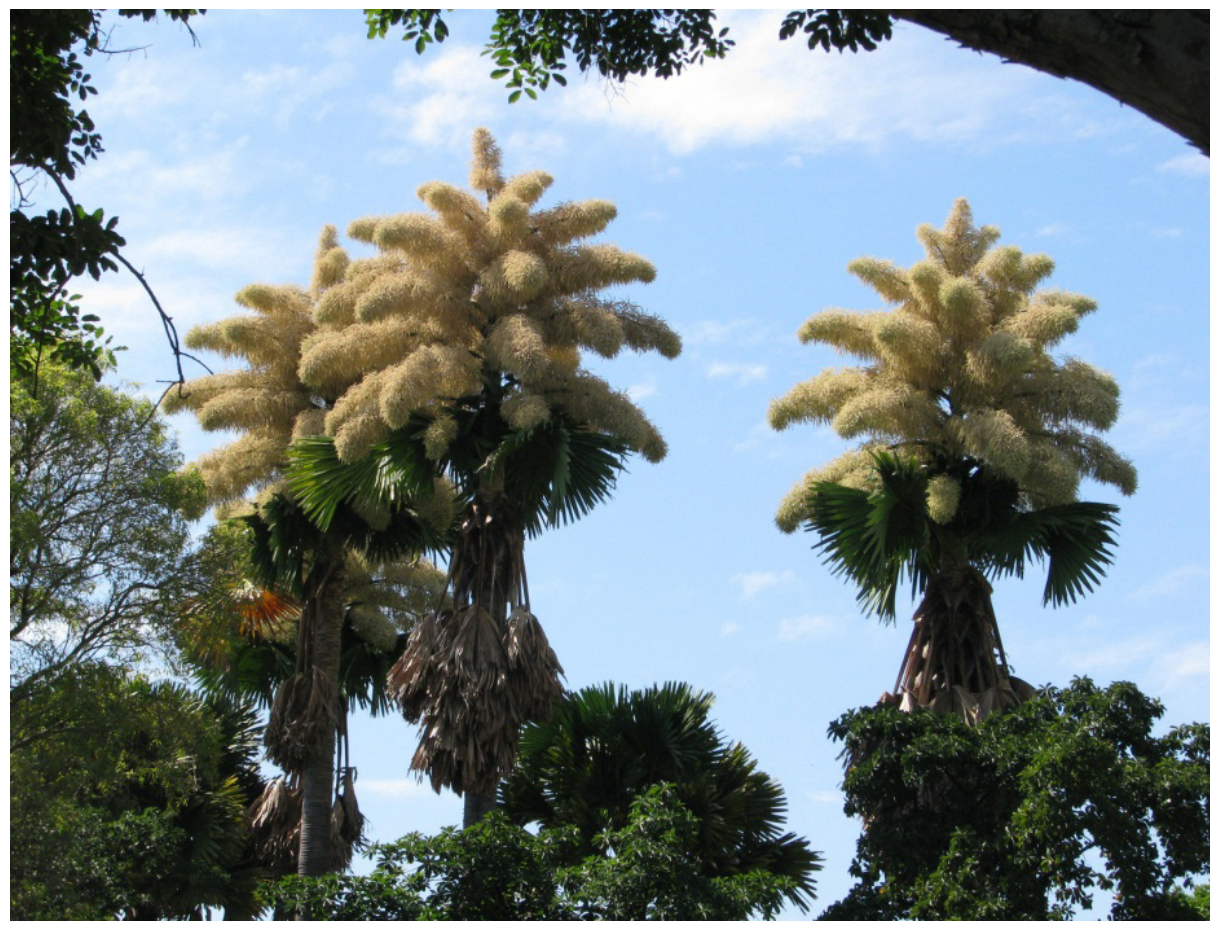

Figura 14: Grupo de corifas e suas gigantescas florações. Foto: Ivete Farah, 2009.

\section{Espécies Singulares na Paisagem - o Caso da Corifa}

Algumas espécies vegetais se destacam na paisagem por determinadas características diferenciadas de porte e de fenologia. Um dos casos mais extraordinários é a corifa ou talipot-palm (Corypha umbraculifera), originária da Índia e do Sri Lanka. Atingindo entre 20 e 25 metros de altura, com grandes e numerosas folhas que formam copa de 12 metros (Lorenzi e Mello Filho, 2001), a corifa se apresenta como um monumento na paisagem. Composta por uma haste de 6 metros de comprimento na parte de cima da planta e milhões de pequenas flores na cor creme, em forma de plumagem, sua inflorescência é considerada a maior do reino vegetal. Em seu local de origem, a corifa ainda ocorre no estado semisselvagem em florestas, mas tem apresentado redução de sua população, necessitando proteção (Dayanandan et al., 2018).

Como espécie monocárpica, a corifa floresce e frutifica uma única vez, morrendo a seguir. Sua inflorescência contribui para o aspecto de impacto na paisagem por sua exuberância e por indicar a iminência de sua morte. Todo o processo dura em torno de dois anos, tempo em que a mensagem passada por essa espécie se intensifica.

Burle Marx a introduziu pela primeira vez em projetos paisagísticos no Parque do Flamengo, onde criou diversos agrupamentos, incluindo mais de oitenta exemplares (Figura 14). Esse plantio reforça o caráter de distinção do projeto no seu aspecto botânico, pelo uso extenso de uma espécie rara no país, responsável por um espetáculo único em sua floração.

\section{Duas Gerações de Corifa no Parque do Flamengo}

A primeira floração da corifa no Parque do Flamengo ocorreu em 1992 (Figura 15), em exemplar próximo ao Monumento dos Pracinhas. Houve uma grande surpresa na época, pois a característica indicada é de que a planta leva de quarenta a setenta anos para florescer, segundo alguns autores (Lorenzi e Mello Filho, 2001), ou entre quarenta e cem anos, segundo outros (Dayanandan et 


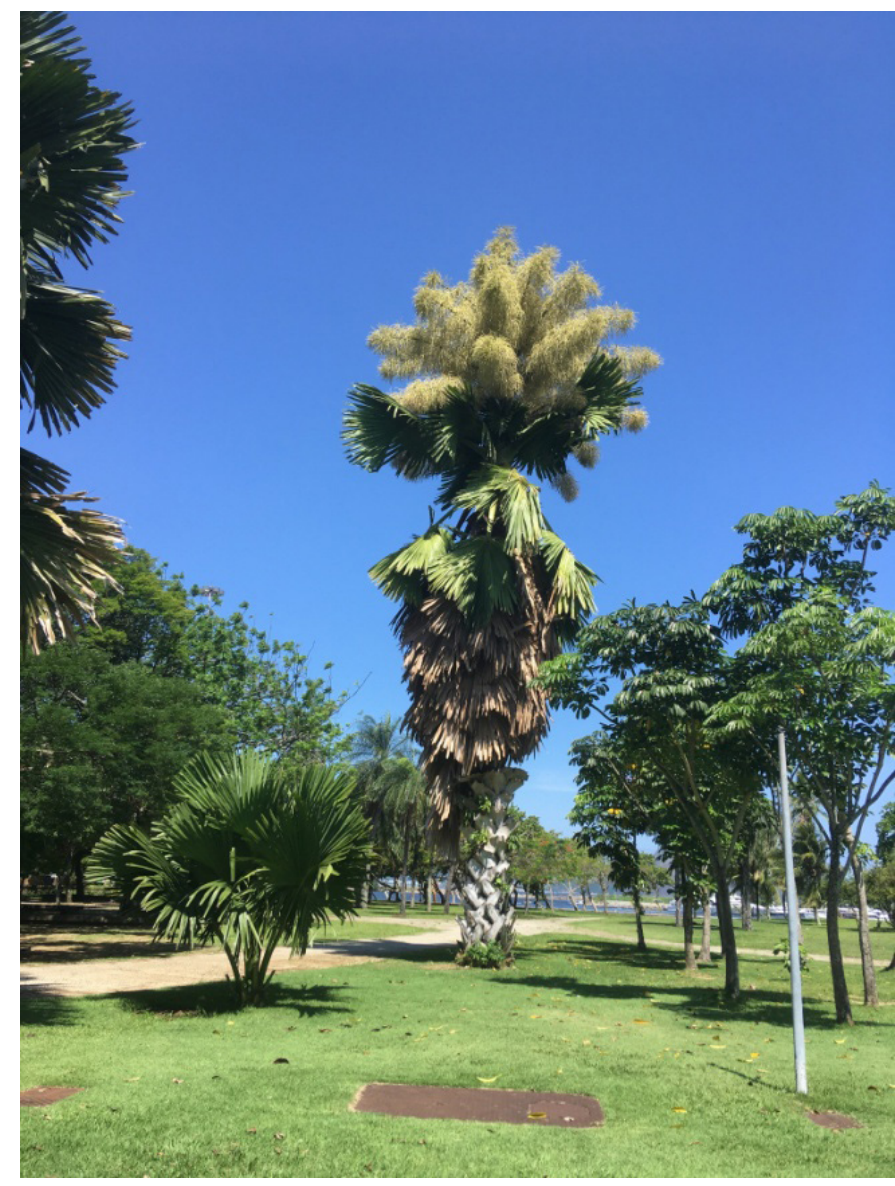

Figura 15: Primeira corifa a florescer no Parque do Flamengo. Foto: Ivete Farah, 1992.

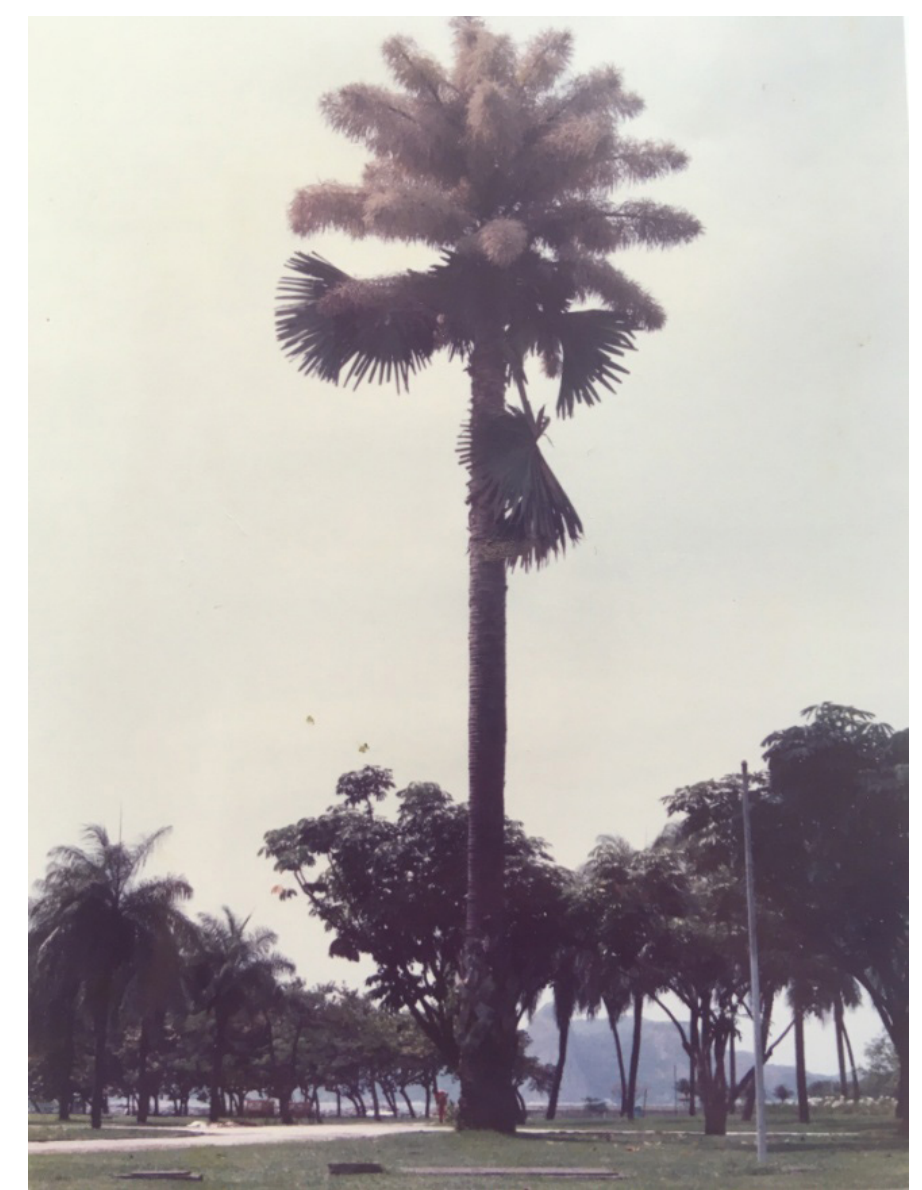

Figura 16: Segunda geração de corifa no Parque do Flamengo em flor.

Foto: Ivete Farah, 2019

Monumento dos Pracinhas, trouxe uma interessante revelação: estava em flor o exemplar plantado para reposição do primeiro que floresceu em 1992, no mesmo local (Figura 16). É a segunda geração de corifas do parque florescendo, portanto, com um tempo de vida ainda mais curto.

A idade de floração das corifas é ressaltada por Dayanandan et al. (2018) e Jacob et al. (2007) como tendo uma considerável variação. Esses últimos, além de apontarem a possibilidade de florescimento mais cedo, a partir de trinta anos, alertam para a necessidade de al. 2018). O indivíduo do parque floresceu antes, com aproximamente trinta anos de vida. Algumas suposições surgiram cor origem, sem que nenhuma delas tenha sido comprovada.

Até hoje, em torno de quarenta exemplares floresceram no parque, alguns com idade mais avançada, variando entorno de quarenta a cinquenta anos. O último grupo de corifas a florescer iniciou o processo em 2019, sendo que uma delas, próxima ao 
maiores estudos dessa questão. As corifas do Parque do Flamengo parecem confirmar essa variação, que deverá ser ainda maior, visto que há vários indivíduos do plantio original que ainda devem florescer. Atualmente, o parque dispõe de exemplares de diversas idades, lado a lado, entre pequenas mudas que foram plantadas ao longo destes anos para substituir as mortas e os indivíduos mais maduros da época da implantação. Há ainda um grupo intermediário, que fez parte de um plantio posterior à inauguração, na década de 1970. Essa variedade de idades vai possibilitar uma continuidade da floração ao longo do tempo.

A corifa promove, a cada florada, um evento duradouro na cena urbana, atraindo apreciadores que desviam seu caminho, sendo alvo de reportagens em diversos veículos de comunicação. Além de seu impacto pela exuberância, é um fenômeno que gera reflexão sobre temporalidades - a da vida humana e a do vegetal. Segundo Leenhardt (2009), Burle Marx utilizou uma palmeira com o tempo de vida similar ao dos seres humanos com a intenção de marcar, na sua permanência e morte, a existência do jardineiro que concebeu seu plantio. Essas referências poéticas, como o nome popular pelo qual também é conhecida - palmeira-do-amor -, revelam a peculiaridade da presença dessa palmeira na cidade.

\section{Conclusão}

Na união da arte com a ciência, há uma alimentação mútua. A arte se torna precisa e a ciência se humaniza. Os projetos paisagísticos, como espaços privilegiados de convivência urbana, têm, a partir de seus elementos vegetais, a oportunidade para a fruição e afeição da paisagem. Reconhecer, estudar e ampliar a vegetação em meio urbano é tarefa fundamental, que exige empenho multidisciplinar.

A presença de valores botânicos de forma lúdica na paisagem cotidiana do carioca aproxima suas mensagens do habitante urbano. Por conseguinte, implica em conhecimento e educação, o que pode ser estimulado a partir de iniciativas como a do projeto de sinalização, realizado em 1999 no Parque do Flamengo, que dispôs placas informativas das espécies de destaque. Infelizmente, o material foi removido após desgaste natural do tempo e não foi reposto.
Além de constituir um banco de sementes, com coletas feitas por instituições e profissionais de paisagismo, o parque apresenta-se como uma oportunidade ímpar para estudos botânicos, fonte de informações sobre o desenvolvimento das espécies que ali se encontram, seja para o acompanhamento com relação à adaptação às condições urbanas, seja para a observação das possíveis diferenças de comportamento dos seus habitats de origem. $\mathrm{O}$ caso da corifa é exemplar nesse aspecto, com a necessidade de realização de estudos científicos, detalhamento botânico e análises comparativas com exemplares em sua região de origem. As corifas cariocas, assim como tantas outras plantas encontradas no Parque do Flamengo, precisam ser conhecidas em suas peculiaridades.

A realização de estudos deve ocorrer em paralelo a ações de preservação. O Parque do Flamengo foi tombado a nível federal, em 1965, e municipal, em 1995, o que Ihe protege com relação a tentativas de alteração de projeto. Entretanto, um grave risco ao patrimônio botânico é a falta de manutenção adequada. A sua conservação atualmente é responsabilidade da Fundação Parques e Jardins (FPJ), da Comlurb, que realiza as podas das árvores da cidade, e da Secretaria Municipal de Conservação.

Em 2000, a Prefeitura do Rio de Janeiro encampou um projeto, colocado a cargo do escritório Burle Marx \& Cia, que buscou revitalizar o parque, envolvendo avaliação da condição fitossanitária da vegetação e respectivo tratamento, reposição das perdas oriundas da morte de alguns exemplares que o inventário de 1992 havia apontado e a retirada de indivíduos em estado irrecuperável. Iniciativas como essas são fundamentais, mas faz-se necessário o monitoramento cotidiano da vegetação. Por sua importância não apenas para o Rio de Janeiro, mas para todo o país, suas dimensões e caráter do projeto, deveria haver um setor específico na FPJ para o gerenciamento da área, realizando estudos em associação com pesquisadores e promovendo o cultivo de espécies, principalmente as raras como a Erythrina x fluminensis e a corifa, por exemplo, em horto da prefeitura.

Atualmente, as condições da vegetação do local, como há 20 anos, inspiram cuidados, com indivíduos doentes e atacados por pragas e risco de descaracterização do projeto. Algumas espécies encontra- 
das em pequeno número em 1992 apresentam redução de exemplares. A Erythrina x fluminensis, por exemplo, diminuiu de seis exemplares para dois, do coco-do-campo, restam apenas dois indivíduos, enquanto a camaçari (Clusia hilariana) não existe mais no parque, significando perda de seu acervo botânico. Muitas corifas que floresceram não foram replantadas. Por outro lado, espécies como a leucena e a munguba, com alta capacidade de reprodução, têm aumentado o número de exemplares.

Patrimônio cultural, paisagístico, ambiental e botânico, o Parque do Flamengo exige especial atenção em busca da manutenção do projeto original, considerando reavaliações e eventuais adaptações. O conjunto das espécies definidas no projeto lhe impõe caráter único e forte identidade na disposição de seus grupamentos vegetais e deve contar com ações que garantam sua integridade e valor para a cidade e sua população.

\section{ReferênCIAs Bibliográficas}

ADAMS, William H. Roberto Burle Marx: the unnatural art of the garden. N. York: The Museum of Modern Art, 1991. 38p.

BENEDICT, Mark; MCMAHON, Edward. Green Infrastructure: linking landscapes and communities. Washington: Island Press, 2006. 299p.

CLÉMENT, Gilles. Le Jardin Comme Index Planétaire. In: ROGER, Alain (org.). La Théorie du Paysage en France: 1974-1994. Seyssel: Editions Champ Vallon, 1995. p. 389-399. COSTA, Lúcia M. S. A. Popular Values for Urban Parks: a case study of the changing meanings of Parque do Flamengo in Rio de Janeiro. 1993. 490f. Tese. (doctor of Philosophy) - University College, Londres, 1993.

DAYANANDAN, P.; LOCKWOOD, M.. SAMUEL, P.; DAYANANDAN, A.; EBENEZER, G. A. I.; GNANASEKARAN, G.; BARNABAS, A. D.; ARISDASON, W; CARY, Edison; ANANDHAPRIYAN, M.; HARRIS, Joseph. Talipot Palm (Corypha sp.): a 50-year vigil on a monocarpic giant flowering tree. Tambaram: Madras Christian College, 2018. Disponível em: www.researchgate.net/publication/328389463 . Acessado em: 22/11/2019. DOI: 10.13140/RG.2.2.13746.25288

DOURADO, Guilherme M. Modernidade Verde: jardins de Burle Marx. São Paulo: Ed. Senac São Paulo / EDUSP, 2009. 385p.

DWYER, John; SCHOEDER, Herbert; GOBSTER, Paul. "The Deep Significance of Urban Trees and Forests". In: PLATT, Rutherford, ROWNTREE, Rowan, MUIK, Pamela (ed.). The Ecological City: preserving and restoring urban biodiversity. Amherst: The University of Massachusetts Press, 1994. p. 137-150

FARAH, Ivete. Arborização Pública e Desenho Urbano: a contribuição de Roberto Burle Marx. 1997. 202f. Dissertação (Mestrado em Urbanismo) - Programa de Pósgraduação em Urbanismo - FAU/UFRJ, Rio de Janeiro. 1997.
FLEMING, Laurence. Roberto Burle Marx: um retrato. Rio de Janeiro: Ed. Index 1996. 160 p.

JACOB, Joemon; SANTHOSH KUMAR, E. S.; MOHANAN, N. Corypha umbraculifera L. a fast depleting palm of South India. Journal of Non-Timber Forest Products. India, v.14, p. 79-80, 2007. Disponível em: https://www.academia.edu/5298487. Acessado em: $30 / 01 / 2021$

LEENHARDT, Jacques. Roberto Burle Marx na História: do modernismo à ecologia. In: CAVALCANTI, Lauro; EL-DAHDAH, Farès. Roberto Burle Marx: a permanência do instável, 100 Anos. Rio de Janeiro, Rocco, 2009 (org.). p. 84-99.

LORENZI, Henri. Árvores Brasileiras: manual de identificação e cultivo de plantas arbóreas nativas do Brasil. 5ed. Nova Odessa, SP: Editora Plantarum, 2009. v.3. 384p. LORENZI, Henri. Árvores Brasileiras: manual de identificação e cultivo de plantas arbóreas nativas do Brasil. 5ed. Nova Odessa, SP: Editora Plantarum, 2008. v.1. 384p. LORENZI, Henri. Árvores Brasileiras: manual de identificação e cultivo de plantas arbóreas nativas do Brasil. 2ed. Nova Odessa, SP: Editora Plantarum, 1998. v.2. 352p. LORENZI, Henri; MELLO FILHO, Luiz Emygdio de. As Plantas Tropicais de R. Burle Marx. São Paulo: Instituto Plantarum de Estudos da Flora Ltda, 2001. 488p. LORENZI, Henri; MOREIRA DE SOUZA, Hermes; MEDEIROS-COSTA, Judas T. de; CERQUEIRA, Luiz Sérgio C. de; VON BEHR, Nikolaus. Palmeiras do Brasil: nativas exóticas. Nova Odessa, SP: Editora Plantarum, 1996. 303p.

LYNCH, Kevin; LUKASHOK, A. Some Childhood Memories of The City. In: BANERJEE, Tridib; SOUTHWORTH, Michael. City Sense and City Design: writings and projects of Kevin Lynch. Cambridge, Massachusetts: The MIT Press, 1990. p. $154-173$.

MACEDO, Silvio. S. A vegetação como elemento de projeto. Paisagem e Ambiente: Ensaios. São Paulo: FAUUSP, n. 4, p. 11-41, 1982. https://doi.org/10.11606/issn.2359 5361.v0i4p11-41

MARTINELLI, Gustavo; MORAES, Miguel A. (org.). Livro Vermelho da Flora do Brasil - 2013. Rio de Janeiro: Andrea Jakobsson: Instituto de Pesquisas Jardim Botânico, 2013. 1100p. Disponível em: http://dspace.jbrj.gov.br/jspui/handle/doc/26. Acessado em: 06/07/2021.

MELLO FILHO, Luiz Emygdio de. Novas Árvores para Uso Paisagístico. In: ENCONTRO NACIONAL SOBRE ARBORIZAÇÃO URBANA, 5, CONGRESSO BRASILEIRO DE ARBORIZAÇÃO URBANA 2 2, 1994, São Luis-MA. Anais... São Luis: EMATER-MA 1994 p. 75-79.

MELLO FILHO, Luiz Emygdio de; CAMISÃO, Cristina; REICHMANN, Felipe; ARAÚJo, Isis; FARAH, Ivete; CABRAL, Maria Inês; LEITMAN, Marta; PELLINI, Rodolfo; WENDT, Tânia O Inventário Florístico do Parque do Flamengo. Revista Municipal de Engenharia. Rio de Janeiro: Prefeitura da Cidade do Rio de Janeiro, v.XLIII, n.1/4, p. 83-102, janeiro/dezembro, 1993.

MELLO FILHO, Luiz Emygdio de. A Arborização do Aterrado Glória-Flamengo. Revista Municipal de Engenharia. Rio de Janeiro: Prefeitura da Cidade do Rio de Janeiro, v.XXX, n.1/4, p. 9-13, janeiro/dezembro, 1962

MOTTA, Flávio. Roberto Burle Marx: e a Nova Visão da Paisagem. 3ed. São Paulo: Nobel, 1986. 255p.

SiBBr. Sistema de Informação sobre a Biodiversidade Brasileira, 2018. Disponível em: https://sibbr.gov.br/. Acessado em: 30/06/2021.

SPIRN, Anne W. O Jardim de Granito: a natureza no desenho da cidade. São Paulo: Ed. da Universidade de São Paulo, 1995. 345p. 
STEFULESCO, Caroline. L'Urbanisme Végetal. Paris: Édition Institut pour le Développment Forestier, 1993. 323p.

ULRICH, Roger S. The role of trees in well-being and health. In: In: RODBELL, Phillip D. (ed.), Proceedings of The Fourth Urban Forestry Conference. St. Louis, Missouri: The American Forestry Association, 1990. p. 25-30.

Ivete Mello Calil Farah

Universidade Federal do Rio de Janeiro. Faculdade de Arquitetura e

Urbanismo.

Prédio da Reitoria/FAU, Av. Pedro Calmon, 550 - Cidade Universitária

da Universidade Federal do Rio de Janeiro, Rio de Janeiro - RJ, 21941 -

485

https://orcid.org/0000-0003-2135-2040

imcfarah@gmail.com

Data de submissão: 19/02/2021

Aceite: 17/09/2021

Revisão: 